\title{
A Comparative Study on the Effect of Contrived vs. Authentic Texts on Iranian Intermediate EFL Learners' Lexical Collocations Learning
}

\author{
Gholamhossein Shabani \\ Department of English, Roudsar and Amlash Branch, Islamic Azad University, Roudsar, Iran \\ E-mail: G.Shabani762@gmail.com \\ Davood Mashhadi Heidar \\ Department of English, Tonekabon Branch, Islamic Azad University, Tonekabon, Iran
}

Received: November 5, 2015 Accepted: Dec.7, 2015 Published: February 1, 2016

doi:10.5296/jse.v6i1.8663 URL: http://dx.doi.org/10.5296/jse.v6i1.8663

\begin{abstract}
The purpose of this research was to investigate the effects of two models of texts (contrived versus authentic texts) on Iranianintermediate EFL learners' lexical collocation learning. The participants were sixtystudents majoring in English. They were students in the second semester of academic year 2015 who were selected through a proficiency test titled Comprehensive English Language Test (CELT),administered at the commencement of the study, the result of which showed that the two groups were homogeneous in terms of their language proficiency.They were divided into two equal comparison groups: The Authentic Text group (AT)and Contrived Text group (CT), either of which included thirty ones. The quantitative data on the participants' knowledge on lexical collocations were collected using a pre-planned pretest on lexical collocation, comprising forty multiple-choice-items. The pretest on lexical collocation went through a pilot study. The same version of the test of lexical collocation, with the rearrangement of some items, was administered to the both comparison groups after the completion of the treatment period for the AT group and placebo for the CT group. The analysis of the quantitative data was done using Independent Samples T-test and paired-samples T-test. The results of the Paired-samples T-test and Independent Samples T-test indicated that the AT group was significantly different from the control group; in other words, the AT group outperformed the CT group. Pedagogical implications and suggestions for further research were included as well.
\end{abstract}

Keywords: Authentic texts, Contrivedtexts,EFL, Intermediate learners, Lexical collocations 


\section{Introduction}

Vocabulary is very crucial to language learners. Through the application of words, learners can communicate and make themselves clear about what they mean. English has thousands of words including vocabulary, collocations, idioms, and expressions. Individuals are able to express what they mean mostly by their choice of vocabulary available to them. Teaching collocation is an important component for second and foreign language learners. If L2 words are not properly taught, students soon will face communicational problems. Allen (1983) indicated the importance of vocabulary development by stating that "through research, the scholars are finding that lexical problems frequently interfere with communication; communication breaks down when people do not use the right words" (p. 5).In addition, Woolard (2000) maintained that collocation has emerged as an important category of lexical patterning and it is becoming an established unit of description in language teaching courses and materials. Liu (2000) also viewed that the more often students are taught English collocations, the more correctly and appropriately they are able to make use of collocations to express what they mean. Scholars such as Bogaards and Laufer (2004), Coady and Huckin (1997), Folse (2004), Nation (1990, 2001), Schmitt (2000), and Schmitt and McCarthy (1997) drew attention to the centrality of second language vocabulary acquisition which has become an increasingly interesting topic of discussion for researchers, teachers, curriculum designers, theorists, and others involved in second language learning. At the same time, research articles focusing on vocabulary issues appeared with regularity. Nunan (1991) argued that possessing adequate level of vocabulary is considered as the most important factor playing role in communication and maintained that L2 learners might not be able to use the structures learned for comprehensible communication without having a good command of vocabulary and collocations as needed.

L2 teachers may embark on a variety of methods to teach vocabulary in L2 situations. Nation (2001) drew attention to a systematic approach to vocabulary instruction by assuming that L2 learners need to focus on vocabulary as a component of the design of communicative task and that vocabulary teaching task should involve integrating it into listening, speaking, reading, and writing. Nation (2001) stressed some influential mechanisms of vocabulary acquisition, in particular, by receiving meaning-focused input via reading and listening, meaning focused-output by speaking and writing, fluency development and language-focused instruction. Likewise, Carter (2001) made point of vocabulary learning explicitly achieved through some techniques nominated as paired translation equivalents, word lists and in variously related semantic sets. He also pointed out that learners can learn vocabulary through more indirect or implicit means, the most notable of which is exposing learners to words in the context of reading real texts. According to Wei (2007), vocabulary is a current focus and a matter of great concern in EFL pedagogy and research. Generally speaking, vocabulary can be represented in different ways, each of which maintains its own advantages and disadvantages. One of these models, according to Prince (1996), is referred to as lexical inferencing, defined as the connections that people establish when they try to interpret texts. Through this model, EFL learners are able to derive the meaning of unknown words using the context in which they appear. Lexical inferencing through contexts provides the learners with 
the chance to grasp vocabulary without the help of the teacher and they can continue their reading without stopping to check words in the dictionary.

The aim of this study was to investigate these two variables and their potential interaction on each other in the Iranian context and shed more light on this by finding any possible effect of contrived and authentic input on the Iranian intermediate EFL learners' lexical collocation knowledge development.

Therefore, the following null hypotheses were formulated in this study:

H01: Contrived texts do not affect Iranian intermediate EFL learners' collocation learning.

H0 2: Authentic texts do not affect Iranian intermediate EFL learners' collocation learning.

H0 3: There is no significant difference between contrived texts and authentic texts in terms of their effect on Iranian intermediate EFL learners' collocation learning.

\section{Review of the Literature}

Schmidt (1994, 1995) asserted that L2 learning involves selecting and encoding the information which is available in the immediate environment to the learners. He, furthermore, held the view that paying particular attention to the input learners receive and also having experience of noticing facilitate learning. As Simard and Wong (as cited in Song, 2007) and Philp (2003) demonstrated, learning takes place as learners pay attention to and notice some certain language features that are pertaining or related to the target language system and structure. Schmidt (1995) highlighted the role played by L2 learners' levels of awareness, making a distinction between two levels of awareness including their awareness at the level of noticing and awareness at the level of understanding. Chang and Sun (2009) stressed the crucial role of collocations in L2 learning by maintaining that collocations ought to be assigned the same kind and level of status in our methodology as other components of language such as pronunciation, intonation, stress, and grammar.

\subsection{Types of Collocations}

In general, two types of collocations are offered by Zarei (2002) including grammatical collocations which relate to the grammatical categories rather than meaning associations and lexical collocations which relate to word associations. Jukneviciene(2008)considered grammatical collocations as the combination of a content or dominant word (verb, noun or adjective) and a grammatical or function word (preposition or structural pattern). Lexical collocations, in contrast, do not contain grammatical elements. They rather comprise a group of words having a certain meaning which co-occur. They also consist of words which possess an approximately equal status. Lewis (2000) shed light on the two categories of lexical and grammatical collocations defining that lexical collocations appear in the form of the combination of two equal lexical components whereas grammatical collocations are the combination of a lexical word, usually a noun, a verb or an adjective along with a grammatical word. In addition, Benson, Benson and Lison's (1997) classification of lexical collocations falls intothe specific categories of Verb + Noun, Adjective + Noun, Noun + Verb, Noun + Noun, Adverb + Adjective, and Verb + Adverb. 


\subsection{Four Collocation Instructional Methods}

The previous studies touched upon the application of four various collocation teaching methods through web-based concordancing practices, traditional methods, implicit, and explicit modes and their effect on the L2 learners' collocations learning.

One innovation in the field of teaching collocations was the introduction of technology-supported learning tools into the language classroom which was very demanding on the part of learners. This method involved using concordances which then led to a new approach in teaching collocation. Collocations were represented primarily via databases of authentic texts which were available to teachers and learners. A concordance, according to Mishan (2004) and Gavioli (2001), stands as a computer program having a large amount of information in the form of language corpora, shows many examples of a key word or phrase. In this approach, some examples of a certain word or phrase are used in contexts and extracted from a corpus. It supplies various information about the features of the language including meaning, functions, syntactic and cultural information, idioms, and collocations. Concordances may be of monolingual, bilingual or multilingual sorts. Sinclair (1991) is supportive of concordancing approach.

Murdoch(1999), Zahar, Cobb and Spada(2001), and Taiwo (2004) found concordancing as a desirable approach for teaching collocations in that it fosters a student-centered instruction by supplying L2 learners with multiple exposures to new items and collocations. They, likewise, enhance learners' participation and enable them to self-discover language features and become aware of words and spoken language. These scholars pointed out to learners' frequency of exposure to the collocations to be learned while Durrant (2008) drew attention to the lack of sufficient input and frequent exposure as a problem to L2 learners. Hadley (2002) assumed that web-based concordancing approach possesses the significant factor for learning some aspects of language in that contextualized instruction or teaching is at the heart of collocation instruction.

There exists exist two conflicting views towards teaching collocations: Implicit versus explicit mechanisms of instructing collocations. Some researchers, the most prominent of whom is Nation (2001), held the position that collocations can be best learned via implicit instruction which is best marked as incidentally learning collocations, the examples of which are extensive reading. There are, however, some researchers who insist on that collocations can be learned explicitly, emanating from direct instruction. Bahns and Eldaw(1993), Nesselhauf (2003), and Seesink(2007) favored explicit processes that involve the construction of explicit knowledge through conscious and deliberative processes. Segler (2001) maintained that this pattern of instructing collocations involves the application of learning strategies on the part of the learner whereas implicit instruction, as stipulated by Celce-Murcia (2001), Hulstijn, Hollander and Greidanus(1996), entails learners' attempt to learn the target items as a by-product of reading a text for comprehension of the content.

A variety of studies were carried out to indicate the positive effects of both explicit and implicit approaches for teaching L2 learners' collocations. Hoffman and Lehmann(2000), Siyanova and Schmitt(2008), and Adolphs and Durow (2004 as cited in Durant, 2008) have indicated the 
merits of explicitly and implicitly teaching collocations to L2 learners. They argued that the preferences for the application of explicit versus implicit mode of teaching collocations rely upon the context of learning and learners' tendency.

The last instructional approach for collocation was nominated traditional approach by incorporating both congruent and non-congruent collocations. The origin of this approach emanated from the work and findings of Odlin (1989) and Arabski (2006) who shed light on the role of L1 in L2 learners' production of English collocations and, accordingly, revealed that L2 learners make use of their L1 knowledge when they lack English collocational knowledge. Bahns and Eldaw (19930 and Nesselhauf (2003) differentiated between two wide concepts of learning congruent collocations and non-congruent ones. The congruent collocations are referred to as those collocations which have equivalent in learners L1 while non-congruent collocations are found to be lacking in equivalent in learners' L1.

\subsection{Empirical Studies on Lexical Collocations}

Zarei and Baniesmaili (2010) undertook a study concerning the effect of different patterns of lexical collocations on the recognition and production of Iranian upper-intermediate learners of English. To this end, some receptive and productive tests of English collocations were given to L2 learners as the participants in the study. Through the study, the participants' recognition of various patterns of lexical collocations was examined, the result of which indicated that the participants' learning of 'adjective + noun' and 'noun + noun' lexical collocation patterns was better. In addition, based on the finding of the study, participants' performance on the production of 'noun + verb' pattern was significantly poorer than the other patterns.

Dilek Akpınar and Bardakçı (2015) investigated the possible impact of teaching collocations by grouping them on L2 learners' retention, incorporating three proficiency levels, namely, upper-intermediate, lower-intermediate and advanced level learners. The findings revealed that there was not a notable difference on the learners' performance retention of collocations as a result of grouping collocations based on grammatical aspect, especially for advanced and lower-intermediate learners. Likewise, there happened no significant difference on the learners' performance on retention of collocations through grouping collocations related to keyword and topic. In other words, as the findings indicated, the learners did not have notable gain of collocation retention when the collocations were offered by grouping them based on topic.

Some studies in the field of second and foreign language learning have particularly examined the effectiveness of two modes of instruction on enhancing collocation. Chan and Liou (2005) made an attempt to study the effect of explicit online instruction on enhancing L2 learners' collocational knowledge. Their findings of the research study was indicative of the point that the learners made significant gains in collocation presented through online instruction. Webb and Kagimoto's (2009) field of research study aimed at examining the effectiveness of learning collocations in a traditionally-based classroom context. To this end, the research was designed based on receptive and productive data-gathering instruments, the result of which 
indicated that contextual learning played a significant role and was assumed an effective approach for learning collocations.

Another study on L2 learners' lexical collocation learning was designed and administered through a computer-assisted language context. Via this study, Chan and Liou (2005) focused on application of synonyms for learning collocation by incorporating a computer assisted language learning (CALL) setting, within which some verb-noun pattern of collocations were classified into four categories according to linguistic criteria such as synonymy, hypernymy, and troponymy, de-lexicalized verb, and non-congruent verb pairs. It was concluded that the L2 learners' performance and gain on de-lexicalized and non-congruent verb pairs was more significant than that on synonymous, hypernymous and troponymous verb pairs.

Goudarzi and Moini (2012) conducted a study and reported the effect of three different kinds of collocation on collocation learning and retention of Iranian EFL university students. The lexical collocations were presented to candidates in authentic reading passages through highlighted (bold), non - highlighted and L1 glossed forms. The Participants were upper intermediate sophomores and juniors. They were supposed to read three passages under three different conditions (bold collocations, L1 glossed collocations, and non-highlighted (text only) collocations. The findings of this research study showed that the students who encountered and experienced lexical collocations in L1 glossed forms in the authentic reading passages outperformed the students in the other two groups and participants to whom the collocations were presented through highlighted enhancement made more significant gain of collocations than the non- highlighted (text only) group.

To examine the impact of collocation instruction on enhancing Iranian EFL learners' reading comprehension,Sadat Kiaee, Heravi Moghaddam, and Moheb Hosseini(2013) designed and completed a quasi-experimental research study. The participants of this study were at intermediate level majoring in English in an EFL English institute. Results of the research work indicated that the students who underwent collocation instruction performed better and more significantly in reading comprehension than the students who received no instruction related to the text before they read the text again in the posttest stage. It was evidenced, in respect with the findings of the study, that teaching collocations play a significant role in enhancing EFL learners' reading comprehension.

Shooshtari and Karami (2013) designed and did a study whose concern was to examine the impact of teaching lexical collocation on Iranian EFL learners speaking ability. The researchers wanted to find out the possible impact using lexical collocations could have on pre-intermediate EFL students' speaking proficiency. To complete the experiment, some EFL learners being at intermediate level were exposed to five common lexical collocation patterns, comprising Verb + Adverb, Noun + Verb, Verb + Noun, Adverb+Adjective, and Adjective+ Noun. The results showed that teaching lexical collocation to intermediate EFL learners exerted a significant effect on their speaking proficiency and a moderate effect on their frequency of the use of lexical collocations. Therefore, the researchers indicated the positive impact of lexical collocation instruction by arguing that receiving instruction on the 
application of lexical collocation patterning can be influential in enhancing EFL students' oral proficiency.

\section{Methodology}

\section{1. Participants}

To collect the required data for the research, a total of 60 Iranian EFL students majoring in TEFL were chosen as the target participants. Their age range was 19 to 25 . To keep and insure the homogeneity of the participants, a proficiency test known as CELT was administered to ninety students majoring in TEFL, out of whom sixty were chosen as the target sampling appropriate for the purpose of the study. According to the CELT scoring,

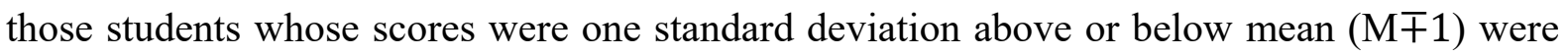
involved as the target sampling. The participants were then assigned to two equal comparison groups, either of whom included thirty ones. One group was assigned as the Authentic Text (AT), and the other group as Contrived Text (CT) group.

\subsection{Materials and Instruments}

The data gathering instruments and materials applied in this study comprised four types as follows:

\subsubsection{The Comprehensive English Language Test (CELT)}

In this study, to determine learners' level of proficiency and keep the homogeneity of the participants under examination, the CELT was used. The aim was to select learners with the same proficiency levels. The test was administered to eighty students. Based on the CELT results, the participants whose score range was one standard deviation above and below the mean (i.e., mean \pm 1 ) were selected to serve the purpose of the researchers.

\subsubsection{Lexical Collocation Pretest and Posttest}

Following the homogeneity test completion, a pretest of lexical collocation was administered to the participants, which totally comprised forty multiple-choice items (recognition type). The preplanned piloted test was constructed in accordance with Zarei's manual (2002), which was intended to be as a course manual on morphology assigned to the students in the university during their course of study. The same sample of collocation multiple-choice-item test, but through the rearrangement of some items, was administered as posttest to the both intended groups.

\subsubsection{Pilot Study}

The test on lexical collocation which determined and administered as the pretest and posttest to the two comparison groups of this study went through a pilot study. To this end, a lexical collocation test composed of 65 multiple-choice items was administered to 40 students having similar characteristics as those of the target groups. Then the poor items of the test were deleted from the final version using the psychometric characteristics of the items such as item facility, item discrimination, and choice distribution, through which a 40multiple-choice-item collocation test was established for the pre-test and post-test purpose. 


\subsubsection{The Material for the Treatment}

The materials selected as the treatment for both groups included twelve reading passages. The reading passages designated for the AT group were all authentic texts, each of which was given within 200 to 220 word limit. Each of the authentic reading text embraced10 to 14 new lexical collocations. These passages were extracted from language teaching materials targeted at intermediate EFL learners' requirement. The newly-represented lexical collocations within each of the reading passages were enhanced through two techniques of bolding or italicizing for both comparison groups. The same textswere given to CT group in contrived or modified form though. To achieve this goal, six of the reading texts were presented in extended or elaborated form, and the rest (including six reading texts) were in summarized form. All of the contrived or modified texts designated for the CT group included the same number of lexical collocations as represented in the authentic texts provided to the AT group.

\subsection{Procedure}

At the commencement of the study, the multiple-choice CELT test was administered to 90 students so as to determine the homogeneity of the participants. Based on the test scores, 60 subjects were selected as the target participants. After the administration of the CELT test and assigning the participants to two equal comparison groups (AT group and CT group), a pretest on lexical collocation including forty multiple-choice items was administered to both groups. Then the participants in the two groups were supposed to receive treatment (treatment for the AT group and placebo for the CT group) within the same period of time through the same material and based on the same methodology. To fulfill the requirement of this study, the treatment material for the AT group included twelve authentic reading passages. The participants of this group were supposed to work on two average-length authentic texts within each session, including 200-220 words for each, into which 10 to 14 lexical collocations were embedded. In general, the twelve reading passages were taught during six sessions of treatment. The participants of this group were asked to work on, learn and practice the meaning of the new lexical collocations by referring to monolingual dictionaries via their definition, synonyms or possible antonyms. They also practiced the collocations through texts in some new examples.

The participants in the CT group passed and underwent six sessions of instruction as treatment as well. They were offered the same reading passages but in modified or contrived forms. As for the participants in the $\mathbf{C T}$ group, the new lexical items in the reading passages were clarified using a monolingual dictionary by means of the techniques of definition, possible synonyms and antonyms, and exemplification. Both of the comparison groups received treatment by the same person using different instructional ways constructed for each group.

The participants of both groups were given a sample collocation exercise to work on at the end of each treatment session. Upon the completion of treatment sessions for the both groups within six sessions, they were administered a post-test, which was the same version of test on lexical collocation administered as pretest, with a rearrangement of some items in the posttest. 


\subsection{Design}

All requirements of a quasi-experimental study, including pretest, posttest, randomization, treatment for the experimental group and placebo for the control group were met in this study. The independent variables of the study were authentic texts and contrived texts, and the dependent variable, as examined in this study, was lexical collocations learning.

\subsection{Data Analysis}

The quantitative data were analyzed using the Statistical Package for the Social Sciences (SPSS) for Windows version 16.Two Paired- Samples t-tests and an Independent-Samples t-test were used to test the null hypotheses of the study and the alpha level for significance testing was set at .05 .

\subsection{Results}

The detailed account the statistical analyses of the quantitative data related to the test and the null hypotheses of this research are represented as follows:

\subsubsection{First Null Hypothesis}

The first null hypothesis of this study stated that "contrived texts do not affect Iranian intermediate EFL learners' collocation learning'.

To examine this hypothesis, a Paired-Samples t-test was conducted. The descriptive statistics are represented in Table 1.

Table 1.Descriptive Statistics of the Paired-Samples t-test for the CT (Contrived Text) Group

\begin{tabular}{|c|c|c|c|c|c|}
\hline & & Mean & $\mathrm{N}$ & $\begin{array}{c}\text { Std. } \\
\text { Deviation }\end{array}$ & $\begin{array}{c}\text { Std. } \\
\text { Error Mean }\end{array}$ \\
\hline \multirow[t]{2}{*}{ Pair 1} & PreCON & 12.06 & 30 & 3.98 & .73 \\
\hline & PostCON & 13.24 & 30 & 2.82 & .52 \\
\hline
\end{tabular}

Table 1 reveals that the posttest mean score (13.20) of the CT (Contrived Text) group was more than the pretest mean score (12.03). The standard deviation for the posttest was less than the pretest, the interpretation of which is an image of less variability among CT group's posttest scores compared to the pretest scores.

In order to find out whether there was a significant difference between the pretest and posttest mean scores of the CT group, the results of Paired-Samples t-test are illustrated in Table 2. 
Table 2. Descriptive Statistics of Paired Differences (CTGroup)

\begin{tabular}{ccccccccc}
\hline & \multicolumn{4}{c}{ Paired Differences } & & \\
\cline { 3 - 7 } & & \multicolumn{3}{c}{ Std. } & & & Sig. \\
& & Mean & Std. Deviation & Error Mean & t & df & (2-tailed) \\
\hline Pair 1 & PreCON - PostCON & 1.17 & 1.63 & .29 & 3.96 & 29 & .000 \\
\hline
\end{tabular}

As shown in Table 2, there is a significant difference, $t(29)=3.94, p=.000)$, between the pretest-posttest mean scores of the CT group. Therefore, the first null hypothesis of the study is rejected.

\subsubsection{Second Null Hypothesis}

In the second hypothesis of the study, it was proposed that 'authentic texts do not affect Iranian intermediate EFL learners' collocation learning.To examine this hypothesis, a Paired-Samples t-test was run for the Authentic Text (AT) group.

Table 3.Descriptive Statistics of Paired-Samples t-test for the AT Group

\begin{tabular}{cccccc}
\hline & & & & \multicolumn{2}{c}{ Std. Error } \\
Pair 1 & PreEX & 12.00 & 30 & 3.96 & .73 \\
& posEX & 15.50 & 30 & 2.50 & .46 \\
\hline
\end{tabular}

As indicated in Table 3, the mean score of AT Group in pretest was calculated to be 12.00 while this value in the posttest was 15.35 . It was concluded that the participants' collocation learning after the treatment provided was impressive and notable. This difference in the mean from the pretest to posttestwas an indication of the rejection of the second null hypothesis. Likewise, standard deviation (Std. Deviation) for the posttest in this group was less than that of the pretest, beingindicative of less variability among AT group's posttest scores than that of the pretest. Likewise, the next table (Table 4) provides further clue regarding the rejection of the second null hypothesis.

Table 4. Paired -Samples t-test for the AT Group

\begin{tabular}{ccccccc}
\hline & \multicolumn{9}{c}{ Paired Differences } & & Sig. \\
\cline { 2 - 4 } & Mean & $\begin{array}{c}\text { Std. } \\
\text { Deviation }\end{array}$ & $\begin{array}{c}\text { Std. } \\
\text { Error Mean }\end{array}$ & T & df & $\begin{array}{c}\text { S-tailed) } \\
\text { (2-tale }\end{array}$ \\
\hline PreEX - posEX & 3.37 & 1.75 & .33 & 10.42 & 29 & .000 \\
\hline
\end{tabular}

By referring to Table 4, there is a significant difference, $\mathrm{t}(29)=10.41, \mathrm{p}=.00)$, between the pretest-posttest mean scores of the AT Group. Therefore, the second null hypothesis of the study, which proposed that authentic texts do not affect Iranian intermediate EFL learners' lexical collocation learning, is rejected. As a result, the second hypothesis is rejected. 


\subsubsection{Third Null Hypothesis}

The third null hypothesis constructed for this study stated that there was no significant difference in the lexical collocation learning of AT input group and CT group. To examine this hypothesis, an Independent-Samples t-test was run. The descriptive statistics of the results are represented in Table 5.

Table 5. Descriptive Statistics for the CT and AT Groups in the Posttest

\begin{tabular}{|c|c|c|c|c|c|}
\hline & Readingtext & $\mathrm{N}$ & Mean & $\begin{array}{c}\text { Std. } \\
\text { Deviation }\end{array}$ & $\begin{array}{c}\text { Std. } \\
\text { Error Mean }\end{array}$ \\
\hline \multirow{2}{*}{$\begin{array}{c}\text { Lexical } \\
\text { collocation }\end{array}$} & Authentic Input & 30 & 15.50 & 2.50 & .46 \\
\hline & Contrived Input & 30 & 13.24 & 2.82 & .52 \\
\hline
\end{tabular}

According to Table 5, the mean of the AT group in the posttest was 15.35 while the mean for theCT group was 13.20. The results showed that the AT group outperformed the CT Group. Therefore, it is concluded that the using authentic texts as an independent variable in this study was more effective than that of contrived texts as the second independent variable. Furthermore, the standard deviation value for the AT group, according to the table, is less than the other group, denoting that there was less variability in the scores of the AT's participants compared with those of the CT group's participants. However, in order to find out whether there was a significant difference between the two groups' mean scores in the posttest, the results of the Independent-Samples t-test are presented in Table 6.

Table 6.Independent-Samples t-test for the CT and AT Groups in the Posttest

t-test for Equality of Means

$95 \%$ Confidence Interval of

Sig. the Difference

\begin{tabular}{|c|c|c|c|c|c|c|}
\hline & & \multirow[b]{2}{*}{$\mathrm{t}$} & \multirow[b]{2}{*}{$\mathrm{df}$} & \multirow{2}{*}{$\begin{array}{c}\text { Sig. } \\
\text { (2-tailed) }\end{array}$} & \multicolumn{2}{|c|}{ the Difference } \\
\hline & & & & & Lower & Upper \\
\hline \multirow{2}{*}{$\begin{array}{c}\text { Lexical } \\
\text { Collocation }\end{array}$} & $\begin{array}{c}\text { Equal } \\
\text { variances } \\
\text { assumed }\end{array}$ & 3.14 & 58 & .003 & .76 & 3.53 \\
\hline & $\begin{array}{l}\text { Equal } \\
\text { variances not } \\
\text { assumed }\end{array}$ & 3.14 & 57.16 & .003 & .76 & 3.53 \\
\hline
\end{tabular}

Table 6 shows that there is a significant difference, $\mathrm{t}(58)=3.13, \mathrm{p}=.003$, between the AT and CT groups. Therefore, the third null hypothesis of the study was rejected

\section{Discussion}

The present study examined the effect of two types of texts (including contrived versus authentic texts) as two prevailing kinds of reading input in EFL contexts on Iranian intermediate EFL learners' lexical collocation learning quantitatively. The findings of this 
study indicated that the contrived texts and authentic texts, both of which are considered as commonly-used reading input in Iranian EFL contexts, were both effective on EFL Learners' collocation learning, but the effect of applying authentic texts was more significant on Iranian intermediate EFL learners' lexical collocation learning as compared to that of the contrived texts. It was then concluded that exposing intermediate EFL learners to authentic material as reading input helped their overall improvement in lexical collocation learning more significantly than that of the contrived material. It was, furthermore, indicated, in accordance with the findings of the study, that learners' collocation learning can be facilitated as they encounter new lexical collocations in the texts which are authentically represented. In other words, the learning of new lexical input as collocations is enhanced through authentic textual representation and vocabulary learning activity is fostered as learners are involved in authentic material.

The results of this study indicated that the learners to whom authentic texts were offered as input experienced significant gains in vocabulary and lexical collocations. Viewing this point, the findings of the study are in line with Chan's and Liou (2005) study in the field of second and foreign language learning by particularly conducting a comparative study on the effectiveness of two modes of instruction on enhancing collocation. They attempted the effect of explicit online instruction versus traditional instruction on enhancing L2 learners' collocational knowledge. What they achieved, through the comparative study, indicated that the learners made significant gains in collocation presented through online instruction. This study was rooted from Webb and Kagimoto's (2009) research study designed to investigate the effectiveness of learning collocations as they were represented in a traditionally-based classroom context. The researchers employed receptive and productive data-gathering instruments, through which they concluded that contextually-based learning played a significant role and was taken an effective approach for learning collocations.

The findings of this study appear to accord with Sadat Kiaee, Heravi Moghaddam, and Moheb Hosseini' (2013) research work whose attempt was to examine the effectiveness of instructing collocation on enhancing Iranian EFL learners' reading comprehension. The participants of this study were at intermediate level, all of whom are majoring in English in an EFL English institute. The results of their work showed that the EFL learners, to whom new collocations were instructed, were observed to have better and more successful performance in reading comprehension than the students who received no instruction related to the text. It was reported, in accordance with the findings of their study, that teaching collocations plays a significant role in enhancing EFL learners' reading comprehension.

This study is, furthermore, in line with Goudarzi and Moini's (2012) research study, via which they conducted a study on the effect of three different kinds of collocation on collocation learning and retention of Iranian EFL university students. The lexical collocations were presented to the EFL learners through authentic reading texts in three forms including highlighted (bold), non - highlighted and L1 glossed forms. The Participants were upper intermediate sophomores and juniors. According to the preplanned requirement. The participants as EFL learners were supposed to read three passages via three different conditions (bold collocations, L1 glossed collocations, and non- highlighted (text only) 
collocations). The findings of this study revealed that the learners who were exposed to lexical collocations in L1 glossed forms in the authentic reading passages outperformed the students in the other two groups; Likewise, the participants whom encountered the new collocations through highlighted enhancement made more significant gain of collocations than the non- highlighted (text only) group.

\section{Conclusion}

Using a quasi-experimental design, the researchers made an attempt to compare the effect of contrived texts and authentic texts on Iranian intermediate EFL learners' lexical collocation learning and development. Statistical figures emanating from the groups' performance illustrated that the AT group outperformed the CT group in their vocabulary and lexical collocation achievement. As students encounter lexical input inauthentic reading passages, their vocabulary learning and collocation gain are fostered and facilitated. Learners' performance in vocabulary learning is more facilitated by eye-catching contexts in which targeted vocabulary are represented. Supplying foreign learners with a list of enhanced words distributed evenly all across reading texts assists them in shaping practical word map in their mind, leading to long retention of information about a word in their mind.

In order to infer the meaning and notion of newly-represented lexical items, language learners try to maintain lively interactions with the instructor and their classmates. Given the Interaction Hypothesis, Long (1996) stressed that although input and output are both necessary for second language acquisition and learning, learners have to pay particular attention to the interactions occurring among them in various contexts. This is of great importance in that learners gain a greater understanding of how this works. According to Long (1996), interactions occurring among students are not only a source of second language input but also rather exchanges that allow the learners to negotiate the meaning of the input. This negotiation results in changes to the complexity of the input.

Being in line with the results of some previous studies, the present study showed that using authentic tests, teachers can help their students to improve their vocabulary knowledge. This study provided English language teachers with information about the importance of authentic materials as reliable sources for developing lexical collocation and the way to use it in different stages of teaching vocabulary. Some benefits can be attributed to the application of authentic material in the EFL classroom which can be accounted for through currently favored theories of second language learning and teaching. Owning to the key role vocabulary plays in communication in general, and in reading comprehension in particular, students' attention should be focused on enhancing word knowledge more seriously than before.

This study was conducted on addressed to Iranian intermediate EFL learners. It is suggested that the future studies of similar nature address other proficiency levels of the EFL learners including upper-intermediate and advanced levels students. It is also suggested that the future studies of similar kind and nature address exclusively males or females. In this study, the effectiveness of authentic and contrived materials were focused on Iranian intermediate EFL learners' lexical collocation learning. The future experiments can focus on the effectiveness 
of these two modes of reading materials on some aspects like grammatical collocations, phrasal verbs, and two-word verbs.

\section{References}

Allen, V. F. (1983). Techniques in teaching vocabulary. New York, N.Y.: Oxford University Press.

Adolphs, S., \& Durow, V. (2004). Social-Cultural Integration and the Development of Formulaic Sequences. In N. Schmitt (Ed.), Formulaic Sequences (pp. 107-126). Amsterdam, Netherlands: John Benjamins.http://dx.doi.org/10.1075/11lt.9.07ado

Arabski, J. (1979). Errors as indicators of the development of interlanguage. Katowice, Polland: Uniwersytet Slaski.

Bahns, J. \& Eldaw, M. (1993). Should we teach EFL students collocations? System, 21(1), 101-114.

Benson, M., Benson, E., \& Lison, R. (1997). The BBI dictionary of English word combinations. Amsterdam: John Benjamin.http://dx.doi.org/10.1075/z.bbi1(2nd)

Bogaards, P., \& Laufer, B. (Eds.). (2004).Vocabulary in a second language. Amsterdam: John Benjamins.http://dx.doi.org/10.1075/11lt.10

Carter, R. (2001). Vocabulary. In R. Carter and D. Nunan (Eds.), The Cambridge guide to teaching English to speakers of other languages (pp. 42-47). Cambridge: Cambridge University Press.http://dx.doi.org/10.1017/CBO9780511667206.007

Celce-Marcia, M. (2001). Teaching English as a Second or Foreign Language. Boston, MA: Heinel \& Heinel Publishers, a Division of Wadsworth, Inc.

Chan, T. P., \& Liou, H. C. (2005). Effects of web-based concordancing instruction on EFL Students' learning of verb - noun collocations. Computer Assisted Language Learning, 18, 231-51.http://dx.doi.org/10.1080/09588220500185769

Chang, W. \& Sun, Y. (2009). Scaffolding and web concordancers as support for language learning. Computer Assisted Language Learning, 22(4), 283-30.http://dx.doi.org/10.1080/09588220903184518

Coady, J., \& Huckin, T. (Eds.). (1997). Second language vocabulary acquisition. Cambridge: Cambridge University Press.

Corpora Galore: Analyses and Techniques in Describing English. Papers from the Nineteenth International Conference on English Language Research on Computerized Corpora (ICAME 1998) (pp. 17-32). Amsterdam: Rodopi.

Dilek Akpınar, K. \& Bardakçı, M. (2015). The Effect of grouping and presenting collocations on retention. TESL-EJ, 18(4), www.tesl-ej.org/wordpress/issues/volume18/ej72. 
Durrant, P. L. (2008). High-Frequency Collocations and Second Language Learning. (Unpublished doctoral dissertation). University of Nottingham, UK. Retrieved May 6, 2008 from http://etheses.nottingham.ac.uk/622/

Folse, K. (2004). Vocabulary myths. Ann Arbor: University of Michigan.

Gavioli, L. (2001). The learner as researcher: Introducing corpus concordancing in the classroom. In Guy Aston (Eds.), Learning with Corpora (pp.108-137). Houston, TX: Athelstan.

Goudarzi, Zahra \& Moini, M. R. (2012). The effect of input enhancement of collocations in reading on collocation learning and retention of EFL learners. International Education Studies,5(3), 247-258.http://dx.doi.org/10.5539/ies.v5n3p247

Hadley, G. (2002). An introduction to data-driven learning. RELC Journal, 33(2), 99-124. http://dx.doi.org/10.1177/003368820203300205

Hulstijn, J. H., Hollander, M., \& Greidanus, T. (1996). Incidental Vocabulary Learning by Advanced Foreign Language Students: The Influence of Marginal Glosses, Dictionary Use, and Reoccurrence of Unknown Words. The Modern Language Journal, 80(3), 327-339. http://dx.doi.org/10.2307/329439

Jukneviciene, R. (2008). Collocations with high-frequency verbs in learner English: Lithuanian learners versus native speakers, Kalbotyra, 59(3), 119- 127.

Lewis, M. (2000). Teaching collocation: Further developments in the lexical approach. Hove, East Sussex: Language Teaching Publications.

Liu, C. P. (2000). A study of strategy use in producing lexical collocations. Selected papers from the tenth International Symposium on English Teaching. (pp. 481-492). Taipei: Crane.

Long, M. H. (1996). The role of the linguistic environment in second language acquisition, A Hand Book of Second language Acquisition. (W. C. Bhatia, Ed.) San Diego, CA: Academic Press.

Mishan, F. (2004). Authenticating corpora for language learning: A problem and its solution. ELT Journal, 58(3), 219-227.http://dx.doi.org/10.1093/elt/58.3.219

Murdoch, Y. (1999). Using authentic texts in the language classroom. (Unpublished master's thesis). Centre for English Language Studies. University of Birmingham, UK.

Nation, P. (2001). Learning vocabulary in another language. Cambridge: Cambridge University Press. http://dx.doi.org/10.1017/CBO9781139524759

Nesselhauf, N. (2003). Collocations in a learner corpus. Amsterdam, Netherlands: John Benjamins.

Nunan, D. (1991). Language teaching methodology. UK: Prentice Hall.

Oldin, T. (1989). Language Transfer: Cross-Linguistic influence in language learning. Cambridge, UK: Cambridge University Press. 
Prince, P. (1996). Second language vocabulary learning: The role of context versus translation as a function of proficiency. The Modern Language Journal, 80, 478-493. http://dx.doi.org/10.1111/j.1540-4781.1996.tb05468.x

Sadat Kiaee, S. S., Heravi Moghaddam, N., \& Moheb Hosseini, E. (2013). The effect of teaching collocations on enhancing Iranian EFL learners' reading comprehension. Journal of Advances in English Language Teaching, 1(1), 1-11.

Schmitt, N. (2000). Vocabulary in language teaching. Cambridge: Cambridge University Press.

Schmitt, N., \& McCarthy, M. (1997).Vocabulary, description, acquisition, and pedagogy. Cambridge: Cambridge University Press.

Seesink, M. T. (2007). Using blended instruction to teach academic vocabulary collocations: A case study. (Unpublished doctoral dissertation). West Virginia. Retrieved September16, 2008from://eidr.wvu.edu/files/4996/Neves_Seesink_MT_dissertation.pdf

Segler, T. M. (2001). Second language vocabulary acquisition and learning strategies in ICALL environments. Computer Assisted Language Learning, 15(4), 409.

Shooshtari, Z. G. \& Karami, N. (2013). Lexical collocation instruction and its impact on Iranian non-academic EFL learners' speaking ability. Journal of Language Teaching and Research, 4(4), 767-776.http://dx.doi.org/10.4304/jltr.4.4.767-776

Sinclair, J.M., (1991). Corpus, concordance, collocation. Oxford: Oxford University Press.

Siyanova, A., \& Schmitt, N. (2008). L2 learner production and processing of collocation: a multi-study perspective. Canadian Modern Language Review, 64(3), 429-458. http://dx.doi.org/10.4304/j1tr.4.4.767-776

Taiwo, R. (2004). Helping ESL learners to minimize collocation errors. The Internet TESL Journal,10(4). http://dx.doi.org/10.1076/call.16.1.83.15528

Webb, S., \& Kagimoto, E. (2009). The effects of vocabulary learning on collocation and Meaning. TESOL Quarterly 43, 55-77.http://dx.doi.org/10.1002/j.1545-7249.2009.tb00227.x

Woolard, G. (2000). Collocation: Encouraging learner independence. In M. Lewis (Ed.), Teaching collocation: Further developments in the lexical approach (pp. 28-46). Hove, UK: Language Teaching Publications.

Zahar, R., Cobb, T., \& Spada, N. (2001). Acquiring reading through reading: Effects of frequency and contextual richness. The Canadian Modern Language Review, 57, 541-572. doi:10.3138/cmlr. 57.4.541.

Zarei, A. (2002). What is wrong with collocations? An investigation of the Iranianadvanced learners' problems with English collocations, Journal of Humanitiesof University of Sistan and Balouchestan, 7(18), 240-280. 
Zarei, A. A.,\& Baniesmaili, N. (2010). Learnability of various patterns of lexical collocations by Iranian upper-intermediate learners of English. IJAL, 13(2), 147-169. 